Оригинални научни рад

УДК 378.147::[371.3:811.111

371.13

Примљен: 31. марта 2021.

Прихваћен: 6. маја 2021.

Радмила В. Бодрич ${ }^{1}$

https://doi.org/10.46630/phm.13.2021.56

Универзитет у Новом Саду

Филозофски факултет

Одсек за англистику

\title{
ЕФИКАСНОСТ МИКРОНАСТАВЕ У РАЗВИЈАҢУ ПРАКТИЧНИХ АСПЕКАТА НАСТАВНИЧКЕ КОМПЕТЕНЦИЈЕ СТУДЕНАТА АНГЛИСТИКЕ
}

\begin{abstract}
Микронастава, као саставни део иницијалног образовања будућих наставника страних језика, омогућава стицање практичних наставних искустава пре обављања саме школске праксе. Овај скраћени наставни формат помаже студентима - будућим наставницима и рефлексивним практичарима - да стекну основне наставне вештине и самопоуздање приликом подучавања, да у пракси примене усвојене теоријске принципе и наставне технике, да открију јаке и слабије стране својих наставних стилова и др. У оквиру скраћеног наставног сегмента студенти подучавају своје колеге самостално изабраним наставним темама, циљано посматрају и критички анализирају одређене аспекте практичне изведбе, и добијају конструктивну повратну информацију од наставника и својих колега.

Циљ овог рада јесте испитивање места и улоге микронаставе као искуствено-рефлексивне праксе у оквиру курса Методика наставе енглеског језика. За потребе рада спроведено је анкетно истраживање међу студентима треће године англистике како би се утврдила ефикасност микронаставе за развијање њихових почетних наставних вештина. На основу перцепције студената англистике покушаћемо да установимо на који начин и у којој мери овај облик рада може да им буде од помоћи да стекну практична искуства и вештине. Резултати спроведеног истраживања ће имати корисне педагошке импликације на потенцијално унапређење микронаставе, како би се студенти још ефикасније и темељније припремили за будућу школску праксу.
\end{abstract}

Кључне речи: микронастава, иницијално образовање, практично искуство, рефлексивна пракса, студенти англистике, истраживање.

1. Увод

Иницијално образовање будућих наставника (страних језика) и њихово професионално усавршавање кључна су питања у свакој земљи 1 radmila.bodric@ff.uns.ac.rs 
јер од квалитета наставника и њихове темељне стручне оспособљености у највећој мери зависе образовна постигнућа ученика². Образовање за одрживи развој поставља пред наставнике страних језика вишеструке и сложене задатке који треба да утичу на повећање ефикасности подучавања и учења страних језика. Да би наставник страног језика, у нашем конкретном случају енглеског као страног језика у потпуности одговорио све већим и захтевнијим изазовима своје струке, потребно је да поседује разноврсна знања, вештине и вредносне ставове (BODRIČ 2017; CINDRIĆ, ANDRAKA i dr. 2014; VIZEK-VIDOVIĆ, VLAHOVIĆŠTETIĆ i dr. 2003, наведено у ĐIGIĆ, 2013: 39; ZVOZDJAK-MAJERS 2011). Прецизније, наставник енглеског као страног језика треба да развије генеричке или опите педагошко-психолошке компетенције које се односе на подучавање у разреду и ван њега, и ученикове индивидуалне особине и вештине (RADIŠIĆ, PAVIČIĆ-TAKAČ і dr. 2007, наведено у CINDRIĆ, ANDRAKA i dr. 2014: 32), и предметно-специфичне компетенције које обухватају а) компетенције везане за англофони језик, књижевност и културу, и/или комуникативне језичке компетенције и интеркултурне компетенције наставника, и б) компетенције везане за подучавање страног језика тј. методичка знања и вештине неопходне за квалитетно подучавање језика (које се стичу на методичким предметима) (BODRIČ 2017: 382-383). Обе врсте компетенција међусобно се преплићу и надопуњавају, и у синергији их треба развијати током иницијалног образовања и каснијег професионалног развоја и напредовања наставника енглеског језика.

Иницијалном образовању наставника страних језика у свету данас се придаје огроман значај. У нашој образовној средини теоријско и практично професионално оспособљавање будућих наставникапрактичара интегрални је део њиховог формалног образовања, а начини њихове реализације показују да се формирању наставника енглеског језика приступа савремено, озбиљно и свестрано. Циљ предмета Методика наставе енглеског језика на Филозофском факултету у Новом Садујесте овладавање теоријским основамаучења и подучавања енглеског као страног језика и оспособљавање студената за извођење практичне делатности у разреду. Иако Методика наставе енглеског језика почива на научно утемељеним основама и будућим наставницима пружа добру теоријску основу, она превасходно има практичну оријентацију како би студенте што боље практично припремила за будућу наставничку професију.

Микронастава, као саставни део иницијалног образовања

2 У раду ће се користити генерички термини наставник и ученик да означе особе женског и мушког пола. 
будућих наставника страних језика, омогућава стицање практичних наставних искустава пре обављања школске праксе на завршној години студија. Овај скраћени наставни формат у оквиру Методике наставе енглеског језика на трећој години основних студија помаже студентима англистике - будућим наставницима и рефлексивним практичарима - да стекну основне наставне вештине и самопоуздање приликом подучавања, да у пракси примене усвојене теоријске принципе и наставне технике, да открију јаке и слабије стране својих наставних стилова и др. У оквиру скраћеног наставног формата студенти подучавају своје колеге самостално изабраним наставним темама, циљано посматрају и критички анализирају одређене аспекте практичног наставног рада, и добијају конструктивну повратну информацију од наставника и својих колега.

Циљ овог рада јесте испитивање места и улоге микронаставе као искуствено-рефлексивне праксе у оквиру курса Методика наставе енглеског језика. За потребе рада спроведено је анкетно истраживање међу студентима треће године англистике како би се утврдила ефикасност микронаставе за развијање њихових почетних наставних вештина. На основу перцепције студената англистике покушаћемо да установимо на који начин и у којој мери овај облик рада може да им буде од помоћи да стекну практична искуства и вештине. Резултати спроведеног истраживања имаће корисне педагошке импликације на потенцијално унапређење микронаставе, како би се студенти англистике још ефикасније и темељније припремили за школску праксу која се реализује на четвртој години студија у васпитно-образовним институцијама.

\section{2. Теоријска разматрања}

Микронастава представља структурисан наставни модел који омогућава стицање (нових) наставних вештина и техника током процеса иницијалног образовања наставника и њиховог стручног усавршавања. Идеју за микронаставу првобитно су дали Двајт Ален и његове колеге (LESTARI 2019; OGEJIK 2009; REDI 2019) на Универзитету у Станфорду 1963. године, за потребе обучавања студената медицинских наука у клиничкој пракси. Осим у области природно-математичких и медицинских наука, микронастава је почела успешно да се примењује у области друштвено-хуманистичких наука, а самим тим и уобласти наставе језика. Иако је заживела 60-их година двадесетог века, микронастава своју ренесансу доживљава у 21. веку потенцирањем позитивистичке методологије, рефлексивне парадигме и приступа подучавања који је усмерен на ученика/студента нудећи драгоцена практична искуства и синергију теорије и праксе (LESTARI 2019; MAKINTOŠ 2010; REDI 2019). 
Замишљена као организован и сажет модел обучавања будућих наставника, микронастава обухвата облик рада где студенти самостално припремају и држе мини-лекцију у временском трајању од 5 до најдуже 20 минута (идеално 10 минута) у мањим групама, критички анализирају и промишљају властите поступке, и добијају конструктивну повратну информацију од колега студената и предметног наставника ради унапређивања наставних вештина и техника (DAMALI 2018; KOČ, ILIJA 2016; PING 2013; RALF 2014; REDI 2019). Постоје разне варијације модела микронаставе (REMEŠ 2013) па се, на пример, мини-лекције могу снимати видео-камером и анализирати, и потом поново држати инкорпорирајући оне аспекте рада који су били предмет дискусије и анализе. Варијације микронаставе зависе од концепције самих предмета чији је она део, наставног плана и програма, броја студената и временске расположивости.

Кључна карактеристика микронаставе јесте њено спровођење у атмосфери пуној подршке и међусобног разумевања, те је и ниво страха од изведбе пред колегама много мањи (DEJVIDS 2016; OGEJIK 2009). Многим студентима англистике, будућим наставницима, микронастава је прво практично искуство пре саме школске праксе која је кључна за развијање њихових наставничких компетенција и формирање чврсте основе њиховог професионалног идентитета. Не изненађује чињеница што се овај искуствени наставни модел сматра ефикасним, аналитичким и контролисаним наставним поступком путем којег студенти стичу и увежбавају наставне вештине и технике у савладивим сегментима (PING 2013: 165; RALF 2014: 17; REDI 2019: 65), повећавају самопоуздање, стрпљење и одговорност за одабир наставних тема и средстава, развијају педагошка уверења, вредности и ставове према наставном процесу, и уче се вештинама планирања часа, циљаног посматрања, критичке рефлексије или промишљања властите делатности и давања позитивних вредносних судова. У иностраној литератури наилазимо на позитивне реакције студената и предавача (BEL 2007: 24, наведено у DEJVIDS 2016: 3) на овај облик стицања практичног искуства, па је тако пронађена висока корелација између практичног наставног рада студената током микронаставе и њихових каснијих изведби (PING 2013: 166), што значи да је микронастава ефикасна и свесна стратегија припремања наставника за наставнички позив (DEJVIDS 2016: 3). Неке студије су дошле до закључка да мини-лекције помажу будућим наставницима: да смање или регулишу ниво анксиозности и страха, да повећају професионалну посвећеност, да подигну свест о значају и комплексности вештине подучавања, да науче да обављају интеракцију с колегама у групи, да стекну искуство у тестирању и вредновању усвојених знања, да рационално и професионално искористе 
унапред задат и ограничен временски оквир, да заинтересују колеге за нове наставне јединице, да усвајају нове наставне технике и стилове подучавања приликом посматрања изведби других колега, да ефикасно користе образовне технологије и управљају разредом (AMOBI 2005; ARENDS 2000; BENTON-KUPER 2001; GOČER 2016; OGEJIK 2009; REDI 2019). У нашој образовној средини, међутим, овакав вид наставе није истраживан и не постоје повратне информације о њеној ефикасности.

С друге стране, може се сматрати ограничењима то што се овај наставни модел не изводи у реалистичном разредном контексту пред ученицима основне или средње школе, затим то што његова реализација одузима много времена, те што због расположивог фонда часова и мањка времена студенти нису у могућности да поново изведу микронаставу и увиде колико су напредовали, као и то што студенти могу да имају страх од прављења грешака пред својим колегама па им то може бити и стресно искуство (RALF 2014: 20; REDI 2019: 70). У сваком случају, користи које овај приступ има далеко превазилазе његова потенцијална ограничења. Микронастава је без сумње успешно искуство учења под условом да се примени на одговарајући начин. Кључно је да се микронастава примени тамо где се најбоље уклапа. То потврђује и тврдња истраживача Ралфа (1998: 109, наведено у RALF 2014: 24)3: „Било који концептуални модел или процедурални оквир у друштвеним наукама... подложан је неупотреби, погрешној употреби или злоупотреби. Такви проблеми се не јављају толико због модела колико због тога како тај модел тумаче или примењују они који га примењују.”

У уводу овог одељка наглашено је да микронастава спада у домен рефлексивне праксе, која је део савремене конструктивистичке парадигме у области иницијалног образовања и усавршавања наставника (BODRIČ 2020: 87). Конструкт рефлексивна пракса представља критичко промишљање и преиспитивање прошле и садашње, туђе као и сопствене, педагошке праксе с циљем њеног унапређивања (BODRIČ 2020; MAKSIMOVIĆ 2011; MAKSIMOVIĆ, BANĐUR 2013; NOVAKOVIĆ 2018; ŠEN 1987). Последњих година, свуда у свету, па и у нашем образовном контексту, рефлексија или социо-конструктивистичко учење постаје саставни део формалног, иницијалног образовања будућих наставника како би студенти, будући наставници и рефлексивни практичари, могли што успешније да превазиђу јаз између својих предубеђења о настави и стварности рада у учионици. Према Максимовић (2011: 112, наведено у NOVAKOVIĆ 2018: 14) поред тога што су „рефлексивни практичари, наставници и васпитачи морају бити и истраживачи сопствене васпитне 3 "Any conceptual model or procedural framework in the social sciences ... is subject to nonuse, misuse, or abuse. Such problems are not inherent in the model as much as they are in how implementers interpret and apply the model." 
праксе”. Ауторка Максимовић врло компетентно тврди да рефлексивни приступ сопственој делатности, наставничкој или истраживачкој, представља предуслов сазнања о томе шта знамо, шта и како заиста радимо, и у чему би требало још да напредујемо како би били што успешнији наставници-практичари (MAKSIMOVIĆ 2011: 812).

Битно је истаћи да рефлексивни приступ практичној делатности може да се примени код било ког наставног метода или приступа, као и да се примени подједнако успешно и код образовања будућих наставника и њиховог каснијег професионалног усавршавања (RIČARDS, LOKART 1996, наведено у BODRIČ 2015: 192). Исто тако, овакав приступ може да обухвати наставне ситуације и искуства учења, или догађаје - прилично сложене и формалне, као и неформалне, те то могу да буду: предавања, учење кроз рад, етнографска истраживања, језичке лабораторије, рад у групи, стручна пракса, учешће у задатку процењивања, дневници учења, хоспитовање у школама, дневници хоспитовања, акциона истраживања, анализа критичних догађаја, студије случаја и сл. Рефлексије могу да се односе на то што наставници мисле, осећају, чине и закључују у време или након практичне делатности/искуства. Рефлексивна пракса се углавном реализује у оквиру методичко-дидактичко оријентисаних предмета током основних студија наставника који се обучавају за будући наставнички позив како би се ефикасно и темељно припремили за циљано посматрање и критичку анализу различитих аспеката образовноваспитног процеса, као и за критичко вредновање сопствене делатности и праксе (прошле и садашње) искусних наставника (GEJ 2011; LI 2007; LOKRAN 1996; MAKSIMOVIĆ, BANĐUR 2013; MAKINTOŠ 2010; MUN 2004; NOVAKOVIĆ 2018; ŠEN 1987; SKRIVENER 2011; ZVOZDJAKMAJERS 2011). У наставку текста укратко ћемо представити структуру модела микронаставе у оквиру предмета Методика наставе енглеског језика на Одсеку за англистику Филозофског факултета у Новом Саду.

\section{1. Модел микронаставе у оквиру Методике наставе енглеског језика}

Без намере да детаљно приказујемо концепцију курса Методика наставе енглеског језика 1 и 2 на Одсеку за англистику Филозофског факултета у Новом Саду, и тиме заначајно премашимо задате оквире овог рада, поновићемо само да основни циљ курса подразумева овладавање теоријским основама учења и подучавања енглеског као страног језика, и оспособљавање студената англистике за извођење практичне делатности у образовно-васпитним институцијама. Иако је од академске 2005/2006. године Методика наставе заступљена као двосеместрални предмет на трећој години основних студија англистике, статус тог предмета и фонд часова (неоправдано) су се мењали током наставних периода у 
прошлости. У сваком случају, главни циљ - с низом потциљева и исхода предмета - изискују од предметног наставника да на најбољи могући начин операционализује постављене циљеве кроз избор одговарајућих наставних приступа, метода, техника, активности, материјала и средстава. Иако су саображене с редоследом излагања теоријске грађе, вежбе Методике наставе морају да имају искључиво практичну оријентацију. Поред демонстрација наставних приступа и метода, уведени су и други облици рада којима се у потпуности развија самосталност или самоиницијатива студената, истраживачки и стваралачки однос према језику који студирају, према раду и будућем позиву. Један од формата који доприноси развоју практичне компетенције студената англистике јесте и микронастава, која се изводи у петом семестру треће године основних студија. Микронастава се темељи на стеченом теоријском и практичном знању и вештинама, иако њима није ограничено. То је уједно и њихово прво практично искуство „подучавања” у учионици, упркос бројним презентацијама које су студенти држали током прве две године студија.

Извођење микронаставе је значајно јер студентима англистике представља прво наставно искуство и оно треба да буде позитивно како би имало дугорочне ефекте на обрасце понашања и деловања у оквиру методичке праксе на четвртој години студија, али и на мотивацију за целоживотно учење и истраживање. Отуда је формат мини-лекције замишљен као десетоминутни наставни сегмент који треба да обухвати кондензовану наставну јединицу, која би у стварном контексту трајала 45 минута. Предметни наставник прво детаљно упознаје студенте с циљевима и структуром мини-лекције, као и с критеријумима оцењивања наставног рада студената. Ти критеријуми су аспекти који се циљано и аналитички посматрају приликом наставног рада студената-наставника, како би се након завршених изведби студенти научили да самостално дају и добијају конструктивну повратну информацију. Предметни наставник претходно студентима демонстрира неколико методички обликованих мини-лекција на одређене теме, како би им тако представио адекватан модел, практично припремио за извођење мини-лекција и мотивисао да овом наставном моделу приступе без анксиозности и страха. Студенти имају потпуну слободу приликом одабира наставних тема, техника и активности. У зависности од тога којим „ученицима” су намењене (ученицима на одређеном нивоу језичког знања или колегама студентима) студенти се стављају у одређене улоге и симулирају пројектовани наставни контекст и језички ниво. Од студената се очекује да приликом извођења мини-лекција прате следећи методолошки оквир од пет фаза4:

4 Ауторка рада се први пут с оваквим методолошким оквиром микронаставе упознала на семинару стручног усаврашавања професора енглеског језика Developing a Standard of Teaching Excellence for Mentors у организацији Института Отворено друштво 
1) Увођење у мини-лекцију (енг. Bridge-in), где студент-наставник објашњава вредност наставне јединице колегама и покушава да их заинтересује за лекцију,

2) Формулисање циљева и исхода мини-лекције (енг. Objective), где студент-наставник јасно и концизно прецизира циљеве и мерљиве исходе учења,

3) Предтестирање (енг. Pre-test), где студент-наставник проверава да ли колеге имају претходно стечено знање о теми, и да ли уопште (и у којој мери) могу да остваре постављене циљеве,

4) Процес активног учења (енг. Participatory learning), где су колеге ангажоване у процесу учења и остваривања зацртаних циљева,

5) Провера усвојеног знања и вештина (енг. Post-test), где студентнаставник разним техникама проверава степен усвојености изложене наставне грађе.

Иако поједностављен, овај наставни формат представља врло ефикасан начин стицања практичног искуства и увођења студената у комплексну и озбиљну методичку праксу која их очекује на завршној години основних студија. Поред тога што стичу и увежбавају нове наставне вештине, студенти англистике развијају језичке вештине из енглеског језика, стичу истанчанији осећај за енглески језик, побољшавају прецизност изражавања на енглеском језику када користе „језик учионице" (енг. classroom jargon) посебно приликом давања упутстава на енглеском језику, успостављања интеракције и постављања различитих врста питања како би се остварио комуникативни циљ наставе енглеског језика и др. Једном речју, студенти уче како да користе циљни језик да би остварили постављене циљеве часа. Иако се овај модел наставе код студената англистике показао врло сврсисходним, барем декларативно, у пракси до сада није истраживана његова ефикасност. Због тога нам је намера била да овим радом покушамо да утврдимо на које све начине и у којој мери овај наставни приступ има своје место и улогу у оквиру курса Методика наставе енглеског језика, и како је студенти англистике доживљавају.

\section{3. Методологија истраживања}

3.1. Циљ истраживања

Истраживање у овом раду имало је за циљ да испита место и улогу микронаставе у оквиру курса Методика наставе енглеског језика 1. Основни проблем истраживања односи се на следеће питање: „Да ли

Хрватска - Програм енглеског језика, у Дубровнику од 1. до 5. јула 2002. 
је и у којој мери микронастава ефикасан начин стицања практичних аспеката наставничке компетенције студената англистике?". Испитивани конструкт смо настојали да сагледамо из педагошко-психолошкометодичке (ППМ) перспективе, те је основни задатак био да утврдимо да ли је, у којој мери и на који начин микронастава корисно практично искуство за студенте англистике. Желели смо, такође, да установимо да ли је микронастава солидна основа за будућу методичку праксу, и да ли помаже студентима англистике да разумеју сложеност наставног процеса и привлачност наставничког позива. У складу с теоријским разматрањима, као и у складу с основним проблемом истраживања формулисана је следећа основна хипотеза: „Студенти англистике ће бити задовољни микронаставом као моделом стицања практичних аспеката наставничке компетенције.."

\section{2. Узорак}

За ово истраживање изабран је намерни узорак. Узорак чине педесет два студента треће године основних студија англистике (в. Табелу 1).

Табела 1. Структура узорка с обзиром на пол

\begin{tabular}{|c|c|c|}
\hline & Број испитаника & Проценат \\
\hline Женски & 38 & $73 \%$ \\
\hline Мушки & 14 & $27 \%$ \\
\hline Укупно & 52 & 100,0 \\
\hline
\end{tabular}

Као што се да видети из приложене Табеле 1, од целокупне популације четрнаест студената је било мушког пола (27\%), а тридесет осам женског пола (73\%), што је очекивана фреквенција будући да студије англистике много чешће уписују девојке него мушкарци. Просек година старости испитаника је 21,46 (Мед.=21). Просечна последња оцена из енглеског језика (Обједињене језичке вештине 4 (ОЈВ 4)) је 8,58 (Мед.=9).

\section{3. Истраживачки инструмент}

У истраживању које је квантитативног типа коришћена је техника анкетирања. Примењен је анкетни упитник комбинованог типа како би се истраживачки проблем дубински сагледао. Од укупно тридесет анкетних питања (тврдњи) двадесет осам су била затвореног, а два отвореног типа. Први део упитника обухватао је три независне социодемографске варијабле које дефинишу испитанике (пол, старост и последња просечна оцена из енглеског језика), а други део упитника је садржао 30 зависних варијабли, којима се тражило да студенти изнесу своје мишљење о свим аспектима микронаставе. Свакој тврдњи (затвореног типа) из упитника 
додата је петостепена скала процене Ликертовог типа: од $1=$ нимало се не слажем до 5 = потпуно се слажем. Студенти су добровољно учествовали и анонимно попуњавали упитник. Истраживање је обављено током часова вежби из Методике наставе енглеског језика 2, средином фебруара 2020. године - на почетку 6. семестра треће године студија англистике.

\section{4. Обрада података}

За обраду података коришћене су мере дескриптивне статистике (фреквенције, проценти, аритметичка средина, медијана) и Пирсонов коефицијент корелације за утврђивање повезаности испитиваних варијабли. Сваку од двадесет осам зависних варијабли упарили смо са све три независне варијабле, али ће због задатих оквира рада бити приказане само статистички значајне и занимљиве корелације, уз адекватно тумачење. Добијени подаци тестирани су статистичким пакетом SPSS 22.00 for Windows. Одговори испитаника на два питања отвореног типа обрађени су методом анализе садржаја којом су се квалитативно анализирали одговори испитаника полазећи од основне јединице анализе - теме. Приликом кодирања одговора, коришћен је индуктивни приступ путем којег су категорије емпиријски утемељене груписањем у скупове истих или сличних ентитета (KNEŽEVIĆ FLORIĆ, NINKOVIĆ 2012; KOEN, MANION i dr. 2007; KRESVEL 2014).

\section{4. Резултати истраживања и дискусија}

\section{1. Квантитативна анализа}

Да би се испитала мишљења студената англистике о ефикасности микронаставе у развијању практичних аспеката наставничке компетенције, спроведено је квантитативно истраживање на узорку од 52 студента. У Табели 2 дате су средње вредности свих зависних варијабли. Израчунате средње вредности налазе се у распону од 2,33 до 4,90.

Табела 2. Средюе вредности испитиваних варијабли

\begin{tabular}{|l|l|l|l|l|l|l|l|l|l|l|l|l|l|l|}
\hline Bap. & $\# 1$ & $\# 2$ & $\# 3$ & $\# 4$ & $\# 5$ & $\# 6$ & $\# 7$ & $\# 8$ & $\# 9$ & $\# 10$ & $\# 11$ & $\# 12$ & $\# 13$ & $\# 14$ \\
\hline Cр.в. & 4,48 & 4,60 & 3,29 & 4,23 & 3,62 & 3,19 & 4,27 & 3,17 & 3,96 & 4,06 & 4,04 & 4,33 & 4,27 & 4,31 \\
\hline Bap. & $\# 15$ & $\# 16$ & $\# 17$ & $\# 18$ & $\# 19$ & $\# 20$ & $\# 21$ & $\# 22$ & $\# 23$ & $\# 24$ & $\# 25$ & $\# 26$ & $\# 27$ & $\# 28$ \\
\hline Ср.в & 4,15 & 3,92 & 3,71 & 4,90 & 4,60 & 4,62 & 4,31 & 3,79 & 3,96 & 2,83 & 2,33 & 4,06 & 4,06 & 4,10 \\
\hline
\end{tabular}

Као што се да видети из приложене табеле, прве четири тврдње које имају највишу средњу вредност јесу тврдња 18 Имао/ла сам потпуну 
слободу приликом избора теме за мини-лекиију и наставних материјала. $(\mathrm{M}=4,90)$, тврдња 20 Микронастава ми је помогла да схватим важност доброг планираға часа. (M=4,62), тврдња 2 Микронастава је курс Методике наставе енглеског језика учинила занимливијим и кориснијим. $(\mathrm{M}=4,60)$, и тврдња 19 Микронастава ми је помогла да приликом планирана и извођена часа будем креативан/на, маштовит/а, одговоран/ на и професионалан/а. $(\mathrm{M=4,60).} \mathrm{Сасвим} \mathrm{оправдано,} \mathrm{испитаницима} \mathrm{код}$ микронаставе највише одговара потпуна слобода приликом избора наставних тема, техника, материјала и активности јер тада заиста могу да прикажу себе и своје вештине у правом светлу. Та одлика, уз друге које ће бити наведене у наставку, микронаставу чини ефикасном, а цео методички курс занимљивијим и кориснијим. Наиме, ограничен временски оквир приморава испитанике да разумеју и науче једну од основних наставних вештина, вештину доброг планирања наставног часа, али дата аутономија их додатно подстиче да буду још креативнији, маштовитији, одговорнији и професионалнији приликом концизног планирања и изведбе мини-лекције. Потреба за аутономијом (TADIĆ 2015) суштински представља једну од основних потреба наставника у наставном процесу. Наставници ће бити више мотивисани за наставни рад када имају професионалну слободу у начину организовања наставе, примени наставних приступа и метода, облика рада с ученицима - док год се остварују циљеви и образовни, васпитни и функционални задаци часа.

Исто тако, испитаници су исказали веома високо слагање с

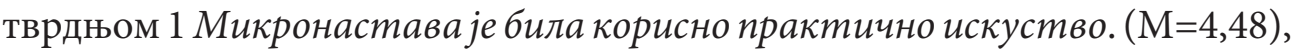
и тврдњом 12 Микронастава је добра припрема за школску праксу на 4. години студија. (М=4,33), тврдњом 14 Повратна инбормација и коментари наставника много су ми користили. (M=4,31), и тврдњом 21 Микронастава ми је помогла да ефикасно повежем теорију и праксу. $(\mathrm{M=4,31).} \mathrm{Ови} \mathrm{резултати} \mathrm{недвосмислено} \mathrm{говоре} \mathrm{да} \mathrm{испитаници}$ микронаставу сматрају врло корисним практичним искуством, које им је помогло да ефикасно повежу знања и вештине стечене на теоријској и практичној настави методичког курса (DEJVIDS 2016; OGEJIK 2009; PING 2013). Повратна информација и коментари наставника су, такође, били значајан извор учења који ће им помоћи да унапреде своје вештине и практичну делатност, а све заједно јасно сведочи о њиховом поимању микронаставе као солидног темеља за будућу методичку праксу на завршној години студија.

Надаље, високо рангиране су и тврдње 7 Микронастава ми је помогла да развијем почетне наставничке компетениије. $(\mathrm{M}=4,27)$ и 13 Микронастава ми је помогла да много научим посматрајући друге 


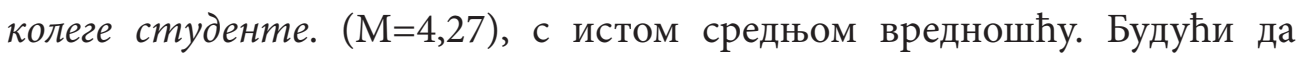
је микронастава прво практично искуство где студенти развијају и увежбавају вештине и знања стечена на методичком курсу, не изненађује то што су студенти англистике позитивно оценили њену ефикасност (AMOBI 2005; LI 2007; PING 2013; RALF 2014; REDI 2019). Исто тако, студенти у великој мери уче и од својих колега студената. Сви студенти су талентовани на различите начине и имају своје стилове подучавања, различите наставне технике, специфичне креативне вештине и идеје па изложеност свему томе представља драгоцен извор учења. Резултати ове две варијабле, као и претходних, говоре у прилог чињеници да су студенти задовољни оваквим практичним обликом рада. Тиме је потврђена основна хипотеза овог истраживања да ће студенти англистике бити задовољни микронаставом као моделом стииаға практичних аспеката наставничке компетенције. И друге варијабле које су високо позициониране у потпуности подржавају основну хипотезу рада и задовољство студената англистике овим наставним моделом: тврдња 4 Микронастава је добра почетна основа за развој

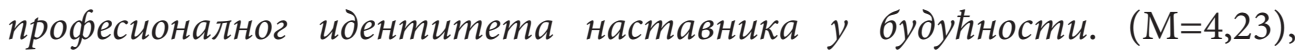
тврдња 15 Повратна информација и коментари колега студената су ми много користили. $(\mathrm{M}=4,15)$, тврдња 28 Микронастава ми је помогла да пазим на коректну употребу језика, добру пројекцију гласа и добар изговор енглеског језика. (M=4,10), тврдња 10 Микронастава ми је омогућила да подучаваюе повежем с темама из свакодневног живота. $(\mathrm{M}=4,06)$, тврдња 26 Микронастава ми је помогла да боле схватим какве личне особине и компетенције добар наставник енглеског језика треба да поседује. $(\mathrm{M=4,06),} \mathrm{тврдња} 27$ Микронастава ми је помогла да увежбам вештину давань јасних и прецизних упутстава и објаштеньа. $(\mathrm{M}=4,06)$ и тврдња 11 Микронастава ми је помогла да откријем јаке и слабије стране свог стила подучавана. $(\mathrm{M}=4,04)$.

Високе средње вредности свих наведених варијабли потврђују да испитаници микронаставу доживљавају као добру почетну основу за развој професионалног идентитета наставника који се гради током целе наставничке каријере. Објективни вредносни судови колега студената су били исто тако корисни као и они које им је наставник упућивао, што је и један од циљева ефикасне микронаставе. Овај наставни модел посебно им је био значајан да развију и увежбају неке од основних наставних вештина попут давања јасних и прецизних упутстава и објашњења на течном и тачном енглеском језику (DEJVIDS 2016; PING 2013; RALF 2014; REDI 2019). Исто тако, модел им је много помогао да открију јаке и слабије стране стилова подучавања, као и личне особине и компетенције које добар/ефикасан наставник енглеског језика треба да поседује како 
би подстакао активно учење и аутентичну употребу језика, уз обавезну персонализацију и повезивање с темама из свакодневног живота. Те одлике модел микронаставе чини сврсисходним, и колико је то могуће аутентичним и природним. Због ограниченог обима рада нећемо детаљно анализирати средње вредности свих зависних варијабли, али свакако би било интересантно навести две последње варијабле које имају најнижу утврђену средњу вредност: тврдњу 24 Микронастава ми је била стресно искуство јер сам током подучавана све време мислио/ла на то да ме наставник и колеге посматрају и оиеньју квалитет мог часа. $(\mathrm{M=2,83)}$ и тврдња 25 Током планирана и извођења мини-часа све време сам имао/ла на уму критеријуме оценивана часа. (M=2,33). Испитаници су исказали најмањи степен слагања с овим двема варијаблама, што значи да микронастава за њих није у великој мери представљала стресно искуство и да су били усредсређени на сам процес подучавања, а не на чињеницу да их наставник и колеге посматрају и критички вреднују аспекте њиховог наставног рада према унапред задатим критеријумима. Овај резултат се подудара с налазима појединих истраживача (DEJVIDS 2016; OGEJIK 2009), који су доказали да је кључна карактеристика микронаставе то што се одвија у атмосфери пуној подршке и међусобног разумевања где сви уче једни од других, исто као и од наставника. Стога је потребно да атмосфера буде позитивна, подстицајна, лишена анксиозности, стреса, страха од прављења грешака и тога што су „под лупом”.

Пирсоновим коефицијентом корелације за утврђивање повезаности испитиваних варијабли установљена је позитивна и значајна корелација између тврдње 1 Микронастава је била корисно практично искуство. и тврдње 2 Микронастава је курс Методике наставе енглеског језика учинила занимљивијим и кориснијим. (0,777 $\left.{ }^{\star *}\right)$, тврдње 5 Микронастава ми је помогла да стекнем више самопоуздана приликом усменог изражаваюа. (0,549**), тврдње 14 Повратна информација и коментари наставника много су ми користили. $\left(0,804^{\star *}\right)$, тврдње 19 Микронастава ми је помогла да приликом планирағьа и извођеть часа будем креативан/на, маштовит/а, одговоран/на и пробесионалан/а. $\left(0,601^{* *}\right)$ и тврдње 27 Микронастава ми је помогла да увежбам вештину давана јасних и прецизних упутстава и објашюена. $\left(0,512^{\star *}\right)$. То нам заправо говори да они испитаници који сматрају да је микронастава корисно практично искуство у највећој мери везују тај став, пре свега, за наставникове повратне информације студентима о свим аспектима њихове изведбе.Испитаницима суконструктивнесугестијезапобољшање одређених аспеката изведбе изузетно значајне јер су свесни да ће тако само унапредити квалитет наставног рада и свих базичних наставних вештина које су тек почели да стичу. У вези с тим, једна од основних вештина 
која је кључна за испитанике јесте вештина давања јасних и прецизних упутстава и објашњења. Способност правилног усменог изражавања на енглеском језику је основ квалитетног подучавања и интеракције између наставника и ученика, а вештим овладавањем овом вештином студенти веома добијају на самопоуздању, о чему сведочи горе наведена повезаност ефикасности микронаставе и развоја ове вештине (BEL 2007; DEJVIDS 2016; OGEJIK 2009; RALF 2014). А да испитаници способност усменог изражавања сматрају базичном наставничком компетенцијом, чији развој је помогао модел микронаставе, говори и статистички значајна веза између тврдње 5 Микронастава ми је помогла да стекнем више самопоуздана приликом усменог изражавана. и 7 Микронастава ми је помогла да развијем почетне наставничке компетениије. $\left(0,546^{* *}\right)$, што је последично и добра припрема за будућу школску праксу (о чему јасно сведочи корелација с тврдњом 12 Микронастава је добра припрема за школску праксу на 4. години студија. (0,506**). Надаље, значајне корелације између свих горе наведених зависних варијабли (1 и 2, 5, 14, $19,27)$ потврђују ставове испитаника да је микронастава курс Методике наставе енглеског језика учинила сврсисходнијим и занимљивијим, а да су они адекватно одговорили задатку јер су подстакнути да буду креативни, маштовити, одговорни и професионални.

Битно је напоменути да је у истраживању утврђено постојање јаких повезаности између многих варијабли и поједине везе се саме по себи подразумевају, што говори о валидности нашег мерног инструмента. Међутим, због обима рада размотрићемо само статистички значајне и занимљиве корелације између варијабли. Тако је позитивна и значајна корелација утврђена између варијабле 3 Микронастава ми је помогла да усавриим језичке вештине. и 6 Микронастава ми је помогла да научим жаргон/језик учионице (classroom jargon) $\left(0,637^{\star *}\right)$, што говори да се побољшање језичких вештина испитаника у оквиру микронаставе махом односи на језик учионице. Ово је важан податак јер језик учионице, ученичка и наставничка реторика значајно утичу на квалитет језичке наставе и усвајање страног језика (REKS, GRIN 2008). Уочене су статистички значајне корелације између варијабле $11 \mathrm{Mu \kappa ронастава} \mathrm{ми}$ је помогла да откријем јаке и слабије стране свог стила подучавань. и варијабле 13 Микронастава ми је помогла да много научим посматрајући друге колеге студенте. $\left(0,533^{* *}\right)$, варијабле 22 Микронастава ми је помогла да развијем основне вештине управљана разредом. $\left(0,557^{\star *}\right)$, варијабле 26 Микронастава ми је помогла да боле схватим какве личне особине и компетенције добар наставник енглеског језика треба да поседује. (0,61 $\left.1^{\star *}\right)$, варијабле 27 Микронастава ми је помогла да увежбам вештину давана јасних и прецизних упутстава и објашюеньа. $\left(0,616^{* *}\right)$, 
и варијабле 28 Микронастава ми је помогла да пазим на коректну употребу језика, добру пројекиију гласа и добар изговор енглеског језика. $\left(0,530^{\star *}\right)$. Испитаници су доказали да им је веома битна интроспекција, критичко промишљање и преиспитивање сопственог наставног рада, јаких и слабијих страна практичне делатности како би усавршили своја знања и вештине. За испитанике су посебно важне основне вештине давања јасних и прецизних упутстава и објашњења, вештине управљања разредом, те коректне употребе језика и добре пројекције гласа и доброг изговора енглеског језика. Микронастава им је, кроз посматрање других својих колега и драгоцених повратних информација које су сви добијали, омогућила да боље схвате профил доброг наставника енглеског језика, којему треба да теже. Исто тако, установљена је јака корелација између варијабле 18 Имао/ла сам потпуну слободу приликом избора теме за мини-лекиију и наставних материјала. и варијабле 19 Микронастава ми је помогла да приликом планираға и извођена часа будем креативан/ на, маштовит/a, одговоран/на и професионалан/а. (0,559**), што значи да им је неограничена слобода приликом избора тема и техника омогућила да искажу сву своју креативност, маштовитост, одговорност и професионалност.

И коначно, изуетно јака повезаност пронађена је између варијабле 26 Микронастава ми је помогла да боле схватим какве личне особине и компетениије добар наставник енглеског језика треба да поседује. и варијабле 27 Микронастава ми је помогла да увежбам вештину даваюа јасних и прецизних упутстава и објашюень. $\left(0,624^{* *}\right)$. Ова јака корелација сведочи да испитаници сасвим оправдано вештину давања јасних и прецизних упутстава и објашњења сматрају једном од основних наставних вештина коју ефикасан наставник страног језика треба да поседује и вешто примењује у наставној пракси.

\section{2. Квалитативна анализа}

Ради добијања још дубљег увида у ставове испитаника о ефикасности микронаставе, у анкетном упитнику постављена су два питања отвореног типа: 29) Молимо Вас да искрено и прецизно образложите зашто Вам се највише допадала микронастава. и 30) Молимо Вас да искрено и прецизно образложите због чега Вам се није допадала микронастава. Анализом одговора на прво питање установљено је да се испитаницима микронастава највище допала због следећих аспеката:

- због прилике да дубље сагледају улогу наставника и код себе препознају таленат за бављење наставничким позивом, 
- због прилике да се ставе у улогу наставника,

- због апсолутне слободе при избору наставних тема и техника, што је само по себи добро мотивационо средство,

- због задатог методолошког оквира који сви треба да следе,

- због повезаности теорије и праксе и прилике да стечено теоријско знање примене,

- због прилике да посматрају реакције колега студената на различите приступе и уче о њиховој ефикасности,

- због неопходности доброг планирања наставног часа и обраћања пажње на временско трајање сваке фазе мини-часа,

- због ретке прилике да употребе енглески језик у току студија,

- због прилике да науче много из разних области живота и рада, не само из области англофоног језика, књижевности и културе,

- због прилике да науче како да дају јасна и концизна упутства колегама „ученицима”,

- због самопоуздања које су стекли приликом обраћања колегама "ученицима” и представљања наставне материје групи „ученика”,

- због научене вештине приликом увођења у наставну јединицу којом проверавају претходно стечено знање ученика,

- због прилике да посматрају, учествују у часу и уче посматрајући друге и слушајући коментаре наставника и колега студената,

- због прилике да науче како да заинтересују колеге за различите наставне теме,

- због прилике да сагледају различите типове будућих наставника енглеског језика, колико добрих (тзв. „мађионичара”), толико и мање добрих.

Тако испитаници искрено поткрепљују своја мишљења на следећи начин (одговори су наведени у оригиналу):

С(тудент/киња) 2: Микронастава ми је дала прилику да сагледам с друге стране како тачно изгледа улога наставника, шта све мора да обухвати и како се то уклапа у моју целокупну слику коју поседујем о себи. Приметила сам да иако морам да порадим на приступу и техникама, имам жељу да преносим знање и да радим с другима. Раније сам мислила да то није за мене, али сада видим да јесте.

C 8: Допала ми се зато што је то практични рад где можемо да вежбамо све оно што смо претходно научили. Да нема практичног дела, тј. микронаставе теорију бисмо врло брзо заборавили. Поред тога, битно је да је то било једно позитивно искуство, где смо имали пуну подршку колега и професорке. Свидело ми се и то што смо добили повратне информације о нашем раду које су биле од велике користи.

С 18: Микронастава ми је била врло занимљива због тога што је било 
мноштво другачијих тема. Имали смо прилику да увидимо шта чини добру наставу или мини-час одличним, а шта мало слабијим или просечним. Због микронаставе неки студенти могу да схвате да имају тај афинитет за наставнички позив и да су „у свом елементу” док предају, и неки тако могу да напредују.

Анализом одговора на последње питање установили смо да се испитаницима микронастава није допала:

- због чињенице да на овакав вид наставе нису навикли и нису били довољно спремни иако су им била дата прецизна упутства и критеријуми за вредновање практичног рада,

- због ограниченог временског трајања мини-часа од 10 минута, иако разумеју да је то због броја студената у целој генерацији и чињенице да сви треба да одрже мини-час у једном семестру,

- због притиска да припреме нешто што ће се свидети њиховим колегама, а да при том не звуче некомпетентно док предају,

- због симулиране ситуације, окружења и услова.

Није било много недостатака микронаставе које су испитаници навели, али свакако се већина односи на то што овај модел није налик школској пракси која се одвија у аутентичном окружењу, с временским трајањем часа од 45 минута и различитим, сложеним и непредвидљивим ситуацијама и проблемима с којима се ученици и наставници сусрећу на дневној основи. Тако испитаници сликовито описују аспекте који им се нису допали:

C 1: Нема конкретног разлога због чега ми се није допала. Можда једина негативна ствар јесте што студенти који нису навикли на усмено излагање могу да се понашају несигурно или нервозно, али овакав вид наставе је ту да помогне у овоме.

C 2: Нисам се осетила довољно спремно, али је то последица тога што нисам знала шта да очекујем од себе и од других студената, без обзира на претходно јасно дата упутства.

С 9: Сматрам да је једини аспект који би могао да се побољша повезан с чињеницом да се микронастава одвијала у вештачки створеним условима тј. пред колегама у улози ученика, па као наставници у овој ситуацији нисмо практично искусили и упознали се с проблемима с којима се професори свакодневно сусрећу.

\section{5. Закључак}

На основу свега реченог, бројни су захтеви и изазови у процесу иницијалног образовања будућих наставника (страних језика). Иницијално образовање не може да опскрби будуће наставнике страних језика свеобухватним знањем и вештинама потребним за подучавање 
које траје током целог животног и професионалног века. Међутим, универзитетско образовање може да им да добре теоријске основе и практичну обуку, који ће бити први корак ка формирању основе њиховог професионалног идентитета и будућег професионалног развоја. Микронастава, као саставни део иницијалног образовања будућих наставника енглеског језика, омогућава развијање и увежбавањепочетних наставничких компетенција пре обављања школске праксе на завршној години основних студија англистике. Занимало нас је како студенти треће године англистике перципирају улогу и место микронаставе у оквиру курса Методика наставе енглеског језика, и да ли, у којој мери и на које све начине овај модел доприноси развијању њихових почетних наставничких компетенција.

Резултати спроведеног истраживања потврдили су основну хипотезу од које се пошло у раду, а то је да ће студенти англистике бити задовољни микронаставом као моделом стицања практичних аспеката наставничке компетенције. Будући наставници енглеског језика микронаставу сматрају врло корисним практичним искуством које им је помогло да схвате важност доброг планирања часа, те да развију вештине ефикасног управљања разредом, давања јасних и прецизних упутстава и објашњења, течне и тачне употребе језика уз добру пројекцију гласа и добар изговор енглеског језика, критичког промишљања и вредновања сопственог практичног рада и свих аспеката наставног процеса, те да примене методе, технике, знања и вештине које су стекли у оквиру методичког курса и педагошко-психолошко-методичких (ППМ) и осталих језичко-књижевно-културно оријентисаних предмета. Овај модел наставе за њих је представљао добру припрему за школску праксу која им предстоји на завршној години студија англистике, као и врло драгоцено искуство које им је помогло да открију добре и слабије стране својих стилова подучавања и да код себе препознају таленат и мотивацију за бављење наставничким позивом. И поред тога што се ради о скраћеном наставном формату он помаже студентима англистике да искажу сав потенцијал, оригиналност, креативност, маштовитост, одговорност и професионалност, стварајући тако добру почетну основу за развој њиховог професионалног идентитета у будућности.

С обзиром да је ово било истраживање квантитативног типа, било би веома корисно спровести и квалитативно или микс-методско истраживање, или чак лонгитудинално истраживање које би додатно помогло у тумачењу ефикасности различитих аспеката овог наставног формата. Коначно, ради добијања још потпунијег увида у мишљења студената англистике и извођења одговарајућих закључака и педагошких импликација, узорак би могао да обухвати и студенте четврте године 
који би, с временске дистанце од годину дана, још објективније могли да анализирају различите аспекте модела микронаставе заснованим на њиховим потребама. Такође, било би врло занимљиво и упутно спровести истраживање међу наставницима језичко-књижевних предмета на основним и мастерским студијама англистике како би се установило да ли се и у ком обиму на тим предметима може увести микронастава као облик стицања практичних искустава и вештина. Ово посебно истичемо јер, као што је у раду речено, током иницијалног образовања студенти англистике не стичу само методичка знања и вештине неопходне за квалитетно подучавање језика, већ и предметно-специфичне компетенције везане за англофони језик, књижевност и културу, што све заједно представља темељ англистичке струке. Наш рад је самим тим наговестио потребу за даљим истраживањима овог модела наставе, која недостају у домаћим и иностраним изворима када је у питању настава страних језика.

\section{Цитирана литература}

AMOBI 2005: AMOBI, Funmi. "Preservice teachers' reflectivity on the sequence and consequences of teaching actions in a microteaching experience." Teacher Education Quarterly, 32(1) (2005): pp. 115-130.

BEL 2007: BELL, Nancy. "Microteaching: What is it that is going on here?" Linguistics and Education, 18 (2007): pp. 24-40.

ARENDS 2000: ARENDS, Richard. Learning to Teach. New York: Mc Graw-Hill, 2000. BENTON-KUPER 2001: BENTON-KUPPER, Jodi. "The microteaching experience: Student perspectives." Education, 121(4) (2001): pp. 830-835.

BODRIČ 2014: BODRIČ, Radmila. „Uloga testiranja i primenljivost ZEO u nastavi gramatike engleskog jezika iz perspektive nastavnika." U: GUDURIĆ, Snežana i Marija STEFANOVIĆ (ur.). Jezici i kulture u vremenu i prostoru III, Tematski zbornik, Novi Sad: Filozofski fakultet (2014): str. 583-597.

BODRIČ 2015: BODRIČ, Radmila. "The Role of Reflective Practice in Pre-Service EFL Teacher Training.” In: LAZAREVIĆ, Nina, Milica SAVIĆ, Tatjana PAUNOVIĆ and Ljiljana MARKOVIĆ (eds.). Teaching Languages and Cultures in the Post-Method Era: Issues and Developments. Niš: Faculty of Philosophy (2015): pp. 189-210.

BODRIČ 2017: BODRIČ, Radmila. „Osvrt studenata anglistike na metodičku praksu kao oblik razvijanja nastavničkih kompetencija." U: GUDURIĆ, Snežana i Biljana RADIĆ BOJANIĆ (ur.). Jezici i kulture u vremenu i prostoru VI, Tematski zbornik. Novi Sad: Filozofski fakultet (2017): str. 379-396.

BODRIČ 2020: BODRIČ, Radmila, „(Ne)intervencionistički pristup obradi gramatike u komunikativnoj nastavi stranih jezika." Nasleđe, 47 (2020): str. 81-101.

CINDRIĆ, ANDRAKA, ŠTEFAN 2014: CINDRIĆ, Ivana, Marija ANDRAKA and Milka BILIĆ-ŠTEFAN. "The Student-Teachers' Perspectives on the Significance and Acquisition of Teaching Competences." Croatian Journal of Edu- 
cation, 16(1) (2014): pp. 11-42.

DAMALI 2018: DAMALIE, Sentumbwe Nakkazi. "Student-Teachers' Experiences of Microteaching on an Economics Methods Course." African Research Review, 12(2) (2018): pp. 101-108.

DEJVIDS 2016: DAVIDS, Mogamat Noor. "Student experiences of microteaching: promoting reproductive or innovative learning." South African Journal of Higher Education, 30(1) (2016): pp. 106-122.

ĐIGIĆ 2013: ĐIGIĆ, Gordana. Ličnost nastavnika i stilovi upravljanja razredom. Doktorska disertacija. Niš: Odsek za psihologiju Filozofskog fakulteta Univerziteta u Nišu, 2013.

GEJ 2011: GHAYE, Tony. Teaching and learning through reflective practice. London \& New York: Routledge Taylor \& Francis Group, 2011.

GOČER 2016: GÖÇER, Ali. "Assessment of the opinions and practices of student teachers on micro-teaching as a teaching strategy." Acta Didactica Napocensia, 9(2) (2016): pp. 33-46.

KNEŽEVIĆ FLORIĆ, NINKOVIĆ 2012: KNEŽEVIĆ FLORIĆ, Olivera i Stefan NINKOVIĆ. Horizonti istraživanja u obrazovanju, Novi Sad: Odsek za pedagogiju Filozofskog fakulteta Univerziteta u Novom Sadu, 2012.

KOČ, ILIJA 2016: KOC, Burcu and Ali ILYA. "Exploring Pre-service Language Teachers' Perceptions and Actual Practices of Giving Feedback in Micro-teaching." Procedia - Socail and Behavioral Sciences, 232 (2016): pp. 421-429.

KOEN, MANION, MORISON 2007: COHEN, Louis, Lawrence MANION and Keith MORRISON. Research Methods in Education. London \& New York: Routledge Taylor \& Francis Group, 2007.

KRESVEL 2014: CRESWELL, John. Research Design: Qualitative, Quantitative, and Mixed Methods Approaches (4th ed.). Los Angeles, London, New Delhi, Singapore, Washington DC: Sage, 2014.

LESTARI 2019: LESTARI, Ika Wahyuni. "Developing Critical Thinking Skills through Microteaching." English, Teaching, Learning, and Research Journal, 5(2) (2019): pp. 297-305.

LI 2007: LEE, Icy. “Preparing pre-service English teachers for reflective practice." ELT Journal, 61(4) (2007): pp. 321-329.

LOKRAN 1996: LOUGHRAN, John. Developing reflective practice: learning about teaching and learning through modelling. London: Falmer Press, 1996.

MAKINTOŠ 2010: MCINTOSH, Paul. Action research and reflective practice. London \& New York: Routledge Taylor \& Francis Group, 2010.

MAKSIMOVIĆ 2011: MAKSIMOVIĆ, Jelena. „Akciona istraživanja i refleksivnost nastavnika." U: Godišnjak SAO za 2010. godinu. Beograd: Srpska akademija obrazovanja (2011): str. 803-816.

MAKSIMOVIĆ, BANĐUR 2013: MAKSIMOVIĆ, Jelena i Veljko BANĐUR. „Savremena akciona istraživanja i metodološko obrazovanje nastavnika refleksivnog praktičara.” Teme, 2, (2013): str. 595-610.

MUN 2004: MOON, Jennifer. A Handbook of Reflective and Experiential Learning: Theory and Practice, London: Routledge Falmer, 2004.

NOVAKOVIĆ 2018: NOVAKOVIĆ, Aleksandar. „Refleksivni model metodičke 
prakse na Filozofskom fakultetu Univerziteta u Nišu.” Metodički vidici, 8 (2018): str. 11-30.

OGEJIK 2009: OGEYIK, Muhlise Cosgun. "Attitudes of the Student Teachers in English Language Teaching Programs towards Microteaching Technique." English Language Teaching, 2(3) (2009): pp. 205-212.

PING 2013: PING, Wang. "Micro-teaching: a powerful tool to embedding the English teacher certification testing in the development of English teaching methodologies." International Journal of English Language and Literature Studies, 2(3) (2013): pp. 163-175.

RALF 2014: RALPH, Edwin. “The Effectiveness of Microteaching: Five Years' Findings." International Journal of Humanities Social Sciences and Education, 1(7) (2014): pp. 17-28.

REDI 2019: REDDY, Rajeshwar. "Teaching How to Teach: Microteaching (A Way to Build up Teaching Skills)." Medical Education, 12(01) (2019): pp. 65-71.

REKS, GRIN 2008: REX, Lesley and Judith GREEN. "Classroom Discourse and Interaction. Reading across the Traditions.” In: SPOLSKY, Bernard and Francis HULT (eds.). The Handbook of Educational Linguistics. UK: Blackwell Publishing (2008): pp. 571-584.

REMEŠ 2013: REMESH, Ambili. "Microteaching: An efficient technique for learning effective teaching." Journal of Research in Medical Sciences, 18(2) (2013): pp. 158-163.

RIČARDS, LOKART 1996: RICHARDS, Jack and Charles LOCKHART. Reflective teaching in second language classrooms. Cambridge, New York: Cambridge University Press, 1996.

SKRIVENER 2011: SCRIVENER, Jim. Learning Teaching: The Essential Guide to English Language Teaching. Oxford: Macmillan Publishers Limited, 2011.

ŠEN 1987: SCHÖN, Donald. Educating the reflective practitioner. San Francisco, CA: Jossey-Bass, 1987.

TADIĆ 2015: TADIĆ, Aleksandar. „Povezanost nastavničkog doživljaja autonomije u školi i njegovog postupanja prema učenicima: pregled savremenih istraživačkih studija.” Zbornik Instituta za pedagoška istraživanja, godina 47, broj 10 (2015): str. 62-80.

VIZEK VIDOVIĆ, VLAHOVIĆ-ŠTETIĆ, RIJAVEC, MILJKOVIĆ 2003: VIZEK VIDOVIĆ, Vlasta, Vesna VLAHOVIĆ-ŠTETIĆ, Majda RIJAVEC i Dubravka MILJKOVIĆ. Psihologija obrazovanja. Zagreb: IEP VERN, 2003.

ZVOZDJAK-MAJERS 2011: ZWOZDIAK-MYERS, Paula. "Reflective practice for professional development." In: Green, Andrew. (ed.). Becoming a reflective English teacher. Berkshire, England: McGraw-Hill Education, Open University Press (2011): pp. 26-43. 
Radmila Bodrič

THE EFFECTIVENESS OF MICROTEACHING IN DEVELOPING PRACTICAL TEACHING COMPETENCES IN EFL MAJORS

Microteaching as an integral part of the pre-service education of future foreign language teachers provides them with the opportunity to gain teaching experience prior to doing their teaching practicum. This condensed teaching format helps students, future teachers and reflective practitioners - to gain basic teaching skills, to develop confidence in teaching, to apply the theoretical principles and teaching techniques they learned about in practice, to discover the strengths and weaknesses of their teaching styles, etc. Within a condensed teaching segment, the students present to their colleagues a topic of their own choice, selectively observe and critically analyse individual aspects of the practical implementation and receive constructive feedback from both the teacher and their colleagues.

The aim of this paper is to examine the place and role of microteaching as an experiential and reflective practice within the EFL Teaching Methodology course. A survey has been conducted among third-year EFL students in order to determine the effectiveness of microteaching as a tool for developing their initial teaching skills. This study is going to try to establish the manner and extent to which this kind of work helps EFL majors acquire practical experience and skills, based on their perceptions. The results of the research will have useful pedagogical implications for the potential enhancement of microteaching so that students could prepare for their future teaching practice more thoroughly and effectively.

Keywords: microteaching, pre-service teacher training, practical experience, reflective practice, EFL majors, survey. 